Vegetalika. 2018. 7(3): 30-40

\title{
Pengaruh Bahan Organik terhadap Pertumbuhan dan Hasil Padi (Oryza sativa L.) Tercekam Salinitas
}

\section{Effect of Organic Matter on the Growth and Yield of Rice (Oryza sativa L.) Under Salinity}

\author{
Fidian Nur Arifiani, Budiastuti Kurniasih*), Rohlan Rogomulyo \\ Departemen Budidaya Pertanian, Fakultas Pertanian, Universitas Gadjah Mada \\ *) Penulis untuk koresponden Email: tuti_b@ugm.ac.id
}

\begin{abstract}
This research aims to study the effect of chicken manure and azolla compost in reducing the impact of salinity stress on rice plants. This research was done by applying different type of organic matters on variable salinity level. The design used in this research was Factorial Randomized Complete Block Design (RCBD). The treatment were without organic matter (BO), the use of chicken manure (B1), and the use of azolla compost (B2), combined with four level of salinity i.e. EC $<0.4 \mathrm{dS} / \mathrm{m}$ or control (SO), $2.5 \mathrm{dS} / \mathrm{m}$ (S1), $5 \mathrm{dS} / \mathrm{m}$ (S2) and $7.5 \mathrm{dS} / \mathrm{m}$ (S3). The results showed that there was no interaction between salinity level and organic matter. There was a decrease in growth and yield of IR-64 rice variety under salinity starting from salinity level of $2.5 \mathrm{dS} / \mathrm{m}$. The reduction of growth included leaf height, shoot fresh weight, shoot dry weight, root dry weight and total dry weight of plant. Whereas reduction on yield parameters were panicle length, panicle weight, number of grain per panicle, weight of 100 grain and total weight of dry grain per hill. Chicken manure had the highest plant height, while azolla green manure provided the highest shoot fresh weight, root fresh weight, root dry weight, number of tiller, total dry weight of plant and number of panicles.
\end{abstract}

Keyword: growth, organic matter, rice plant, salinity stress, yield.

\section{INTISARI}

Penelitian ini bertujuan untuk mempelajari pengaruh macam bahan organik berupa pupuk kandang ayam dan pupuk hijau azolla dalam mengurangi dampak cekaman salinitas pada tanaman padi. Rancangan perlakuan yang digunakan pada penelitian ini yaitu Rancangan Acak Kelompok Lengkap (RAKL) Faktorial. Penelitian ini dilakukan dengan mengaplikasikan jenis bahan organik berbeda pada beberapa tingkat salinitas. Perlakuan jenis bahan organik terdiri dari tiga aras yakni tanpa bahan organik (B0), penggunaan pupuk kandang ayam (B1), dan penggunaan pupuk hijau azolla (B2), sedangkan perlakuan tingkat salinitas terdiri dari empat aras yaitu $\mathrm{EC}<0,4 \mathrm{dS} / \mathrm{m}$ atau kontrol (S0), 2,5 dS/m (S1), $5 \mathrm{dS} / \mathrm{m}$ (S2) dan 7,5 dS/m (S3). Hasil penelitian menunjukkan bahwa tidak terdapat interkasi antara perlakuan tingkat salinitas dan jenis bahan organik. Terjadi penurunan pertumbuhan dan hasil secara nyata pada tanaman padi varietas IR-64 yang tercekam salinitas dimulai dari tingkat salinitas 2,5 $\mathrm{dS} / \mathrm{m}$ pada parameter pertumbuhan luas daun, bobot segar tajuk, bobot kering tajuk, bobot kering akar, bobot kering total tanaman. Sementara pada parameter hasil terjadi 
penurunan pada panjang malai, bobot malai, jumlah gabah per malai, bobot 100 butir gabah bernas dan bobot gabah kering giling total per rumpun. Pupuk kandang ayam menghasilkan tinggi tanaman tertinggi, sedangkan pupuk hijau azolla memberikan hasil tertinggi pada bobot segar tajuk, bobot segar akar, bobot kering akar, jumlah anakan, bobot kering total tanaman dan jumlah malai.

Kata kunci: pertumbuhan, bahan organik, padi, cekaman salinitas, hasil

\section{PENDAHULUAN}

Padi merupakan tanaman pangan penting kedua di dunia setelah gandum. Selain itu, padi menjadi sumber makanan pokok hampir $40 \%$ dari populasi penduduk dunia dan makanan utama penduduk Asia Tenggara (Grubben \& Partohardjono, 1996). Peningkatan populasi penduduk menyebabkan kebutuhan akan padi juga meningkat. Mengingat hal tersebut, maka produktivitas padi perlu dijaga bahkan ditingkatkan untuk mendukung ketahanan pangan dunia. Di Indonesia penyempitan lahan akibat alih fungsi semakin membuat lahan produktif tidak tersedia. Penyempitan lahan tersebut mendorong para petani untuk menggunakan lahan marginal sebagai tempat untuk membudidayakan tanaman padi. Salah satu contoh lahan marginal yaitu lahan salin. Lahan salin merupakan lahan yang mengandung kadar garam yang tinggi sehingga dapat menghambat pertumbuhan dan perkembangan tanaman (Hoeft, 2001).

Untuk mengurangi dampak cekaman salinitas diperlukan teknologi budidaya, diantaranya dengan cara menetralkan pengaruh $\mathrm{NaCl}$ di lingkungan perakaran. Salah satu yang dapat dilakukan yaitu dengan penambahan bahan organik ke dalam tanah. Bahan organik berfungsi sebagai bahan pembenah tanah sekaligus dapat membantu tanaman dalam penyerapan unsur hara (Islam et al., 2014). Contoh bahan organik yang dapat digunakan yaitu pupuk kandang ayam dan pupuk hijau azolla. Pupuk kandang ayam mengandung berbagai unsur yang dibutuhkan oleh tanaman. Salah satu pupuk kandang yang biasa digunakan yaitu pupuk kandang ayam. Berdasarkan hasil penelitian Gupta et al. (2001), pada kondisi salin pupuk kandang ayam mampu meningkatkan kandungan fosfor tersedia dalam tanah yang dapat dimanfaatkan oleh tanaman pada beberapa tingkat salinitas. Pupuk kandang ayam juga meningkatkan ketersediaan nitrogen dalam tanah sehingga nitrogen dapat tersedia bagi tanaman.

Selain pupuk kandang, bahan organik lainnya yaitu pupuk hijau. Salah satu tanaman yang dapat dimanfaatkan sebagai pupuk hijau yaitu azolla. Azolla merupakan tanaman air yang banyak dijumpai karena mudah tumbuh. Azolla bersimbiosis dengan Anabaena azollae yang memiliki kemampuan memfiksasi nitrogen sehingga azolla dapat menyediakan berbagai unsur hara bagi tanaman terutama nitrogen. Penelitian ini 
Fidian Nur Arifiani et al., / Vegetalika. 2018. 7(3): 30-40

bertujuan untuk memperoleh pengaruh macam bahan organik berupa pupuk kandang ayam dan pupuk hijau azolla dalam mengurangi dampak cekaman salinitas pada tanaman padi.

\section{BAHAN DAN METODE PENELITIAN}

Penelitian ini dilaksanakan di Rumah Kaca, Departemen Budidaya Pertanian, Fakultas Pertanian, Universitas Gadjah Mada, Yogyakarta. Adapun kegiatan pengamatan sampel destruktif tanaman dilakukan di Laboratorium Manajemen dan Produksi Tanaman, Fakultas Pertanian, Universitas Gadjah Mada, Yogyakarta. Penelitian ini dilaksanakan pada bulan Juli hingga Oktober 2017.

Perlakuan disusun menggunakan Rancangan Acak Kelompok Lengkap (RAKL) Faktorial. Faktor pertama adalah tingkat salinitas dengan empat aras $\mathrm{NaCl}$, yakni: $\mathrm{EC}<$ 0,4 dS m-1 (S0), 2,5 dS m $\mathrm{m}^{-1}$ (S1), $5 \mathrm{dS} \mathrm{m}^{-1}$ (S2) dan 7,5 dS m $\mathrm{m}^{-1}$ (S3). Faktor ke dua yaitu perlakuan jenis bahan organik dengan tiga aras, yakni : tanpa bahan organik (B0), pemberian pupuk kandang ayam (20 ton ha-1) (B1), pemberian pupuk hijau Azolla (9 ton ha-1) (B2).

Perlakuan tingkat salinitas diberikan 7 hari sekali dan dicek ECnya setiap minggu agar nilainya sesuai dengan perlakuan yang dikehendaki. Air salin yang

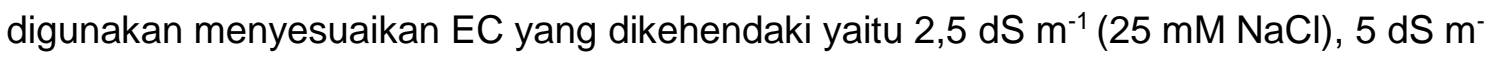
1 (50 mM NaCl) dan 7,5 dS m ${ }^{-1}$ (75 mM NaCl), sedangkan pada perlakuan <0,4 dS m ${ }^{-1}$ digunakan air biasa atau air kran. Pupuk kandang ayam yang digunakan merupakan pupuk kandang yang sudah matang ditandai dengan tekstur pupuk yang remah dan menyerupai tanah serta tidak berbau, sedangkan pupuk hijau azolla yang digunakan berasal dari azolla segar. Pemberian bahan organik dilakukan dengan cara membenamkan pupuk kandang ayam dan pupuk hijau azolla ke dalam polibag yang sudah berisi tanah saat persiapan media.

Dalam penelitian ini terdapat 12 kombinasi perlakuan dengan 3 blok sebagai ulangan. Masing-masing kombinasi perlakuan digunakan 5 polibag pada tiap blok. Jadi dalam penelitian ini terdapat 12 kombinasi perlakuan $\times 3$ ulangan $\times 5$ tanaman yakni 180 polibag. Pengambilan sampel destruktif dilakukan 2 kali yakni pada 25 dan 55 hari setelah pindah tanam serta panen.

Data yang diperoleh dianalisis dengan Analisis Sidik Ragam (ANOVA). Jika diperoleh hasil yang berbeda nyata maka dilakukan uji lanjut Duncan Multiple Range Test (DMRT) dengan taraf kepercayaan 95\%. 
Fidian Nur Arifiani et al., / Vegetalika. 2018. 7(3): 30-40

HASIL DAN PEMBAHASAN

Salinitas dapat menghambat pertumbuhan dan perkembangan tanaman akibat dampak yang ditimbulkannya. Menurut Chaum et al. (2011), salinitas menyebakan tanaman mengalami keracunan ion $\mathrm{Na}^{+}$dan $\mathrm{Cl}^{-}$menyebabkan cekaman osmotik dan ionik pada sel sehingga akan menghambat pertumbuhan dan perkembangan tanaman. Untuk itu, diperlukan suatu bahan yang dapat digunakan untuk mengurangi dampak dari cekaman salinitas tersebut, salah satunya bahan organik. Bahan organik yang digunakan yaitu pupuk kandang ayam dan pupuk hijau azolla. Berdasarkan hasil penelitian yang dilakukan oleh Shaban et al. (2009) pada tanah salin, diperoleh hasil bahwa pupuk kandang ayam mampu meningkatkan konsentrasi unsur hara mikro seperti Fe, Mn, dan Zn pada padi. Pupuk kandang ayam mampu menghasilkan unsur hara mikro yang lebih tinggi dibandingkan dengan perlakuan penggunaan pupuk mineral lainnya. Sementara menurut Raja et al. (2012), pupuk hiaju azolla dapat menurunkan electrical conductivity (EC) pada tanah salin, $\mathrm{pH}$ masam dan menigkatkan kandungan kalsium pada tanah.

Daun merupakan tempat terjadinya proses fotosintesis pada tanaman. Dari proses fotosintesis tersebut kemudian dihasilkan asimilat yang digunakan untuk pertumbuhan tanaman. Variabel luas daun tanaman (Tabel 1) menunjukkan beda nyata pada perlakuan tingkat salinitas umur 50 hst. Luas daun pada perlakuan tingkat salinitas $5 \mathrm{dS} / \mathrm{m}$ dan $7,5 \mathrm{dS} / \mathrm{m}$ memberikan hasil yang nyata lebih rendah dibandingkan kontrol. Menurut Djukri (2009) salinitas dan luas daun memiliki hubungan terbalik. Semakin tinggi salinitas maka luas daun akan semakin menurun. Menurunnya luas daun diduga karena tanaman kehilangan turgornya karena cekaman osmotik yang terjadi sehingga tanaman tidak mampu memperluas daunnya.

Sementara pada perlakuan jenis bahan organik tidak memberikan hasil yang berbeda nyata pada parameter luas daun umur 25 hst maupun 50 hst. Menurut Longstreth \& Nobel (1979), cekaman salinitas dapat memicu perubahan pada ketebalan daun. Daun menjadi lebih sukulen sebagai respon terhadap cekaman salinitas. Hal ini dilakukan untuk menurunkan resistensi terhadap penyerapan $\mathrm{CO}_{2}$ serta meningkatkan laju fotosintesis dengan cara meningkatkan permukaan internal daun. Oleh karena itu, dihasilkan luas daun yang tidak berbeda nyata karena daun lebih memfokuskan diri untuk mempertebal permukaannya. 
Fidian Nur Arifiani et al., / Vegetalika. 2018. 7(3): 30-40

Tabel 1. Luas daun pada berbagai perlakuan bahan organik dan tingkat salinitas

\begin{tabular}{lrr}
\hline Perlakuan & \multicolumn{2}{c}{ Luas daun $\left(\mathrm{cm}^{2}\right)$} \\
\cline { 2 - 3 } & $25 \mathrm{hst}$ & $50 \mathrm{hst}$ \\
\hline Jenis Bahan Organik & & \\
Tanpa Bahan Organik & $53,10 \mathrm{p}$ & $816,7 \mathrm{p}$ \\
Pupuk Kandang Ayam & $43,55 \mathrm{p}$ & $1074,65 \mathrm{p}$ \\
Pupuk Hijau Azolla & $56,46 \mathrm{p}$ & $1185,01 \mathrm{p}$ \\
\hline Tingkat Salinitas & & \\
$<0,4 \mathrm{dS} / \mathrm{m}$ & $57,89 \mathrm{a}$ & $1233,51 \mathrm{a}$ \\
$2,5 \mathrm{dS} / \mathrm{m}$ & $53,76 \mathrm{a}$ & $1095,73 \mathrm{ab}$ \\
$5 \mathrm{dS} / \mathrm{m}$ & $46,52 \mathrm{a}$ & $775,21 \mathrm{~b}$ \\
$7,5 \mathrm{dS} / \mathrm{m}$ & $45,97 \mathrm{a}$ & $\mathbf{7 3 0 , 6 8 \mathrm { b }}$ \\
\hline Interaksi & $(-)$ & $(-)$ \\
\hline Koefisien keragaman $(\%)$ & $\mathbf{3 0 , 5 3}$ & $\mathbf{1 3 , 2 0}$ \\
\hline
\end{tabular}

Keterangan : (-) menunjukkan tidak ada interaksi, angka yang diikuti huruf yang sama menunjukkan tidak adanya beda nyata pada uji Duncan's Multiple Range Test (DMRT) pada taraf kepercayaan $95 \%$.

Bobot kering tajuk tanaman (Tabel 2) tidak memberikan hasil yang berbeda nyata pada perlakuan jenis bahan organik pada umur 25 hst, 50 hst maupun 100 hst. Bahan organik membutuhkan waktu yg lama untuk terurai sehingga belum banyak unsur hara tersedia bagi tanaman. Hal ini menyebabkan bobot kering tajuk tanaman tidak berbeda nyata pada perlakuan jenis bahan organik.

Tabel 2. Bobot kering tajuk tanaman pada berbagai perlakuan bahan organik dan tingkat salinitas

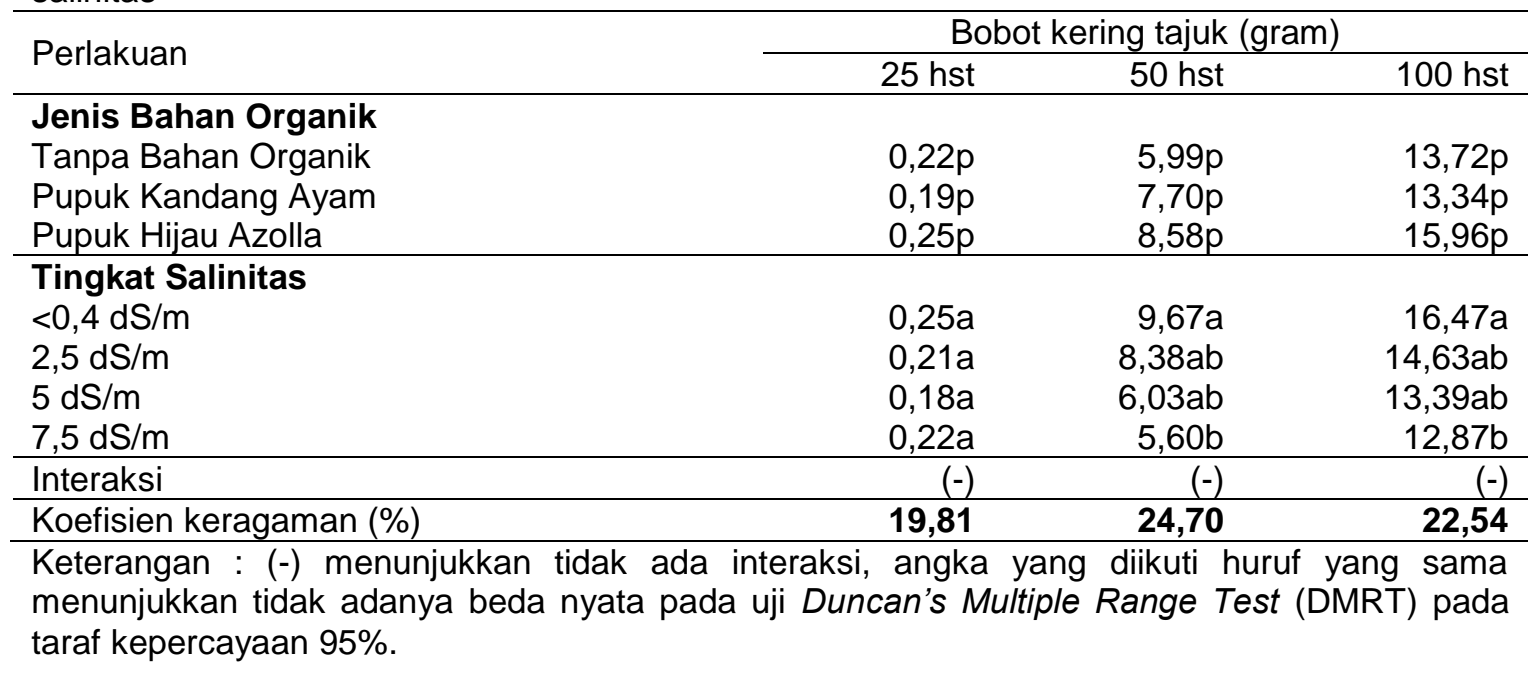

Pada perlakuan tingkat salinitas menunjukkan beda nyata pada umur 50 dan 100 hst. Perlakuan 7,5 dS/m nyata lebih rendah dibandingkan perlakuan $<0,4 \mathrm{dS} / \mathrm{m}$ (kontrol). Pada tanaman yang tercekam salinitas, konsentrasi garam di dalam tanah yang lebih tinggi dibandingkan pada jaringan tanaman dapat menyebabkan terjadinya plasmolisis sehingga tanaman mengalami dehidrasi atau kekurangan air (Levitt, 1980). Air merupakan salah satu bahan yang digunakan tanaman untuk fotosintesis. Artinya, 
Fidian Nur Arifiani et al., / Vegetalika. 2018. 7(3): 30-40

jika tanaman kekurangan air maka fotosintesis akan terganggu dan menyebabkan hasil asimilat rendah sehingga biomassa yang dihasilkan juga rendah.

Beda nyata pada perlakuan tingkat salinitas dihasilkan pada umur 50 hst dan 100 hst. Pada umur 50 hst, perlakuan $5 \mathrm{dS} / \mathrm{m}$ dan $7,5 \mathrm{dS} / \mathrm{m}$ menghasilkan bobot kering akar nyata lebih rendah dibandingkan perlakuan $<0,4 \mathrm{dS} / \mathrm{m}$ (kontrol), sedangkan pada umur 100 hst perlakuan $5 \mathrm{dS} / \mathrm{m}$ menghasilkan bobot kering akar yang nyata lebih rendah dibandingkan perlakuan kontrol. Peningkatan akumulasi garam dalam tanah diduga menyebabkan bobot kering akar rendah.

Tabel 3. Bobot kering akar pada berbagai perlakuan bahan organik dan tingkat salinitas

\begin{tabular}{lrrr}
\hline \multirow{2}{*}{ Perlakuan } & \multicolumn{3}{c}{ Bobot kering akar (gram) } \\
\cline { 2 - 4 } & $25 \mathrm{hst}$ & $50 \mathrm{hst}$ & $100 \mathrm{hst}$ \\
\hline Jenis Bahan Organik & & & \\
Tanpa Bahan Organik & $0,03 \mathrm{pq}$ & $2,04 \mathrm{p}$ & $2,40 \mathrm{p}$ \\
Pupuk Kandang Ayam & $0,02 \mathrm{q}$ & $3,77 \mathrm{p}$ & $2,00 \mathrm{p}$ \\
Pupuk Hijau Azolla & $0,04 \mathrm{p}$ & $3,92 \mathrm{p}$ & $2,46 \mathrm{p}$ \\
\hline Tingkat Salinitas & & & $2,81 \mathrm{a}$ \\
$<0,4 \mathrm{dS} / \mathrm{m}$ & $0,03 \mathrm{a}$ & $4,86 \mathrm{a}$ & $2,31 \mathrm{ab}$ \\
$2,5 \mathrm{dS} / \mathrm{m}$ & $0,02 \mathrm{a}$ & $4,57 \mathrm{ab}$ & $1,93 \mathrm{~b}$ \\
$5 \mathrm{dS} / \mathrm{m}$ & $0,03 \mathrm{a}$ & $1,75 \mathrm{~b}$ & $2,11 \mathrm{ab}$ \\
$7,5 \mathrm{dS} / \mathrm{m}$ & $0,04 \mathrm{a}$ & $1,79 \mathrm{~b}$ & $(-)$ \\
\hline Interaksi & $(-)$ & $(-)$ & $\mathbf{1 6 , 5 3}$ \\
\hline Koefisien keragaman (\%) & $\mathbf{1 9 , 2 1}$ & $\mathbf{2 3 , 7 2}$ & $\mathrm{sama}$
\end{tabular}

Keterangan : (-) menunjukkan tidak ada interaksi, angka yang diikuti huruf yang sama menunjukkan tidak adanya beda nyata pada uji Duncan's Multiple Range Test (DMRT) pada taraf kepercayaan $95 \%$

Bobot kering total tanaman yang disajikan pada Tabel 4 menggambarkan jumlah seluruh asimilat yang terkandung dalam tanaman. Pada umur $25 \mathrm{hst}$, terdapat beda nyata pada perlakuan jenis bahan organik. Perlakuan pupuk hijau azolla menghasilkan bobot kering total tanaman nyata lebih tinggi dibandingkan perlakuan kontrol. Menurut Ahmed et al. (2010), pupuk hijau azolla dapat meningkatkan bobot kering dan pengisian bulir tanaman. Selain itu, azolla mampu memperbaiki kapasitas menahan air pada tanah sehingga air dapat tersedia bagi tanaman (Aribawa et al., 2004 cit. Maulida, 2011). Pada kondisi salin, tanaman kesulitan menyerap air karena terjadinya cekamana osmotik. Penambahan pupuk hijau azolla membuat air dapat diserap oleh tanaman dan membuat tanaman dapat tumbuh secara optimal sehingga bobot kering totalnya meningkat.

Pada umur 50 hst dan 100 hst beda nyata dihasilkan pada perakuan tingkat salinitas. Perlakuan $5 \mathrm{dS} / \mathrm{m}$ dan $7 \mathrm{dS} / \mathrm{m}$ bobot kering total tanaman nyata lebih rendah dibandingkan perlakuan kontrol saat 50 hst, sedangkan saat umur 100 hst semua 
Fidian Nur Arifiani et al., / Vegetalika. 2018. 7(3): 30-40

tingkat salinitas yakni 2,5 dS/m, $5 \mathrm{dS} / \mathrm{m}$ dan 7,5 dS/m menghasilkan bobot kering total tanaman yang nyata lebih rendah dibandingkan perlakuan kontrol. Pada tanaman yang tercekam salinitas terjadi penghambatan pertumbuhan dimulai dari sulitnya penyerapan air dan unsur hara dalam tanah karena tingginya garam dalam tanah yang menyebabkan potensial osmotik rendah. Kekurangan air tersebut menyebabkan pertumbuhan tanaman terhambat sehingga bobot kering total yang dihasilkan rendah.

Tabel 4. Bobot kering total tanaman pada berbagai perlakuan bahan organik dan tingkat salinitas

\begin{tabular}{lrrr}
\hline \multirow{2}{*}{ Perlakuan } & \multicolumn{3}{c}{ Bobot kering total tanaman (gram) } \\
\cline { 2 - 4 } Jenis Bahan Organik & $25 \mathrm{hst}$ & $50 \mathrm{hst}$ & $100 \mathrm{hst}$ \\
Tanpa Bahan Organik & & & \\
Pupuk Kandang Ayam & $0,24 \mathrm{pq}$ & $8,03 \mathrm{p}$ & $25,99 \mathrm{p}$ \\
Pupuk Hijau Azolla & $0,21 \mathrm{q}$ & $11,47 \mathrm{p}$ & $24,66 \mathrm{p}$ \\
\hline Tingkat Salinitas & $0,29 \mathrm{p}$ & $12,50 \mathrm{p}$ & $28,62 \mathrm{p}$ \\
$<0,4 \mathrm{dS} / \mathrm{m}$ & & & \\
$2,5 \mathrm{dS} / \mathrm{m}$ & $0,28 \mathrm{a}$ & $14,54 \mathrm{a}$ & $32,29 \mathrm{a}$ \\
$5 \mathrm{dS} / \mathrm{m}$ & $0,24 \mathrm{a}$ & $12,96 \mathrm{ab}$ & $26,94 \mathrm{~b}$ \\
$7,5 \mathrm{dS} / \mathrm{m}$ & $0,21 \mathrm{a}$ & $7,78 \mathrm{~b}$ & $24,15 \mathrm{~b}$ \\
\hline Interaksi & $0,2 \mathrm{a}$ & $7,38 \mathrm{~b}$ & $22,31 \mathrm{~b}$ \\
\hline Koefisien keragaman $(\%)$ & $(-)$ & $(-)$ & $(-)$ \\
\hline Ke & $\mathbf{2 1 , 0 5}$ & $\mathbf{2 9 , 3 1}$ & $\mathbf{1 8 , 6 4}$ \\
\hline
\end{tabular}

Keterangan : (-) menunjukkan tidak ada interaksi, angka yang diikuti huruf yang sama menunjukkan tidak adanya beda nyata pada uji Duncan's Multiple Range Test (DMRT) pada taraf kepercayaan $95 \%$.

Pada Tabel 5 terlihat bahwa tinggi tanaman menghasilkan beda nyata saat umur 25 hst pada perlakuan bahan organik. Perlakuan pupuk kandang ayam menghasilkan tinggi tanaman yang nyata lebih tinggi dibandingkan perlakuan kontrol dan pupuk hijau azolla. Menurut Dikinya \& Mufwanzala (2010), pupuk kandang ayam mampu meningkatkan kandungan $\mathrm{N}$ secara signifikan hingga $50 \%$. $\mathrm{N}$ berperan dalam pertumbuhan organ vegetatif tanaman. Tingginya unsur $\mathrm{N}$ yang tersedia bagi tanaman membuat pertumbuhan tinggi tanaman dapat meningkat.

Pada variabel jumlah anakan (Tabel 5) didapatkan hasil yang berbeda nyata pada perlakuan jenis bahan organik. Perlakuan pupuk hijau azolla menghasilkan jumlah anakan yang nyata lebih tinggi dibandingkan perlakuan kontrol. Hal tersebut dapat disebabkan karena pupuk hijau azolla dapat memperbaiki aerasi tanah sehingga unsur hara yang diserap oleh akar lebih optimal dan menghasilkan pembentukan jumlah anakan yang tinggi. Menurut Arifin (2001), kandungan $\mathrm{N}$ yang meningkat pada tanah karena suplai $\mathrm{N}$ dari azolla dapat menyebabkan peningkatan tinggi tanaman dan jumlah anakan padi. 
Fidian Nur Arifiani et al., / Vegetalika. 2018. 7(3): 30-40

Tabel 5. Tinggi tanaman dan jumlah anakan pada berbagai perlakuan bahan organik dan tingkat salinitas

\begin{tabular}{|c|c|c|c|}
\hline \multirow{2}{*}{ Perlakuan } & \multicolumn{2}{|c|}{ Tinggi tanaman $(\mathrm{cm})$} & \multirow{2}{*}{ Jumlah anakan } \\
\hline & $25 \mathrm{hst}$ & $50 \mathrm{hst}$ & \\
\hline \multicolumn{4}{|l|}{ Jenis Bahan Organik } \\
\hline Tanpa Bahan Organik & $44,25 q$ & $100,27 q$ & $8,75 q$ \\
\hline Pupuk Kandang Ayam & $49,84 p$ & $102,93 q$ & $10,17 p q$ \\
\hline Pupuk Hijau Azolla & $42,78 q$ & $102,70 q$ & $11,58 p$ \\
\hline \multicolumn{4}{|l|}{ Tingkat Salinitas } \\
\hline$<0,4 \mathrm{dS} / \mathrm{m}$ & $47,10 a$ & $102,65 a$ & $10,78 a$ \\
\hline $2,5 \mathrm{dS} / \mathrm{m}$ & $45,07 a$ & $103,33 a$ & $10,44 a$ \\
\hline $5 \mathrm{dS} / \mathrm{m}$ & $45,00 \mathrm{a}$ & $102,11 a$ & $9,78 \mathrm{a}$ \\
\hline $7,5 \mathrm{dS} / \mathrm{m}$ & $45,32 a$ & $99,77 a$ & $9,67 \mathrm{a}$ \\
\hline Interaksi & $(-)$ & $(-)$ & $(-)$ \\
\hline Koefisien keragaman (\%) & 16,34 & 6,80 & 29,29 \\
\hline 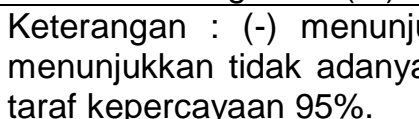 & si, & $\begin{array}{l}\text { diikuti } \\
\text { Range }\end{array}$ & $\begin{array}{l}\text { uruf yang sama } \\
\text { st (DMRT) pada }\end{array}$ \\
\hline
\end{tabular}

Jumlah malai (Tabel 6) menghasilkan beda nyata pada perlakuan jenis bahan organik. Perlakuan pupuk hijau azolla menghasilkan jumlah malai yang nyata lebih tinggi dibandingkan perlakuan kontrol dan pupuk kandang ayam. Azolla dapat membantu mensuplai N untuk tanaman. Menurut, De Datta (1981), unsur N yang diserap tanaman pada saat fase pembentukan malai dapat meningkatkan jumlah malai tanaman.

Tabel 6. Jumlah malai, panjang malai, dan bobot malai pada berbagai perlakuan bahan organik dan tingkat salinitas

\begin{tabular}{lrrrr}
\hline Perlakuan & $\begin{array}{c}\text { Jumlah } \\
\text { malai }\end{array}$ & $\begin{array}{r}\text { Panjang malai } \\
(\mathrm{cm})\end{array}$ & $\begin{array}{c}\text { Bobot malai } \\
(\mathrm{gram})\end{array}$ & \multicolumn{1}{c}{$\begin{array}{c}\text { Jumlah gabah } \\
\text { per malai }\end{array}$} \\
\hline Jenis Bahan Organik & & & & \\
Tanpa Bahan Organik & $6,83 \mathrm{q}$ & $22,82 \mathrm{p}$ & $15,02 \mathrm{p}$ & $109,92 \mathrm{p}$ \\
Pupuk Kandang Ayam & $6,75 \mathrm{q}$ & $22,45 \mathrm{p}$ & $14,36 \mathrm{p}$ & $105,00 \mathrm{p}$ \\
Pupuk Hijau Azolla & $8,33 \mathrm{p}$ & $22,11 \mathrm{p}$ & $15,85 \mathrm{p}$ & $103,08 \mathrm{p}$ \\
\hline Tingkat Salinitas & & & & \\
$<0,4 \mathrm{dS} / \mathrm{m}$ & $8,22 \mathrm{a}$ & $23,43 \mathrm{a}$ & $19,11 \mathrm{a}$ & $118,33 \mathrm{a}$ \\
$2,5 \mathrm{dS} / \mathrm{m}$ & $7,11 \mathrm{a}$ & $22,62 \mathrm{ab}$ & $15,80 \mathrm{ab}$ & $108,45 \mathrm{ab}$ \\
$5 \mathrm{dS} / \mathrm{m}$ & $6,89 \mathrm{a}$ & $22,27 \mathrm{ab}$ & $13,95 \mathrm{bc}$ & $103,44 \mathrm{ab}$ \\
$7,5 \mathrm{dS} / \mathrm{m}$ & $7,00 \mathrm{a}$ & $21,52 \mathrm{~b}$ & $11,43 \mathrm{c}$ & $93,78 \mathrm{~b}$ \\
\hline Interaksi & $(-)$ & $(-)$ & $(-)$ & $(-)$ \\
\hline Koefisien keragaman $(\%)$ & $\mathbf{2 1 , 4 7}$ & $\mathbf{2 , 8 5}$ & $\mathbf{2 4 , 5 2}$ & $\mathbf{1 8 , 3 8}$ \\
\hline
\end{tabular}

Keterangan : (-) menunjukkan tidak ada interaksi, angka yang diikuti huruf yang sama menunjukkan tidak adanya beda nyata pada uji Duncan's Multiple Range Test (DMRT) pada taraf kepercayaan $95 \%$.

Panjang malai (Tabel 6) pada perlakuan salinitas 7,5 dS/m menghasilkan nilai yang nyata lebih rendah dibanding kontrol. Hal tersebut diduga karena tanaman menggunakan energinya untuk menghindarkan diri dari cekaman dibandingkan untuk memproduksi hasil. Panjang malai mempengaruhi bobot malai karena panjang malai 
Fidian Nur Arifiani et al., / Vegetalika. 2018. 7(3): 30-40

berkaitan dengan jumlah gabah. Semakin pendek malai maka jumlah gabah yang dihasilkan semakin rendah (Tabel 6). Rendahnya jumlah gabah yang dihasilkan pada tingkat salinitas tertinggi yakni 7,5 dS/m membuat bobot malai yang dihasilkan juga rendah (Tabel 6).

Tabel 7. Presentase jumlah gabah isi, bobot 100 butir gabah bernas, dan bobot kering giling total per rumpun pada berbagai perlakuan bahan organik dan tingkat salinitas

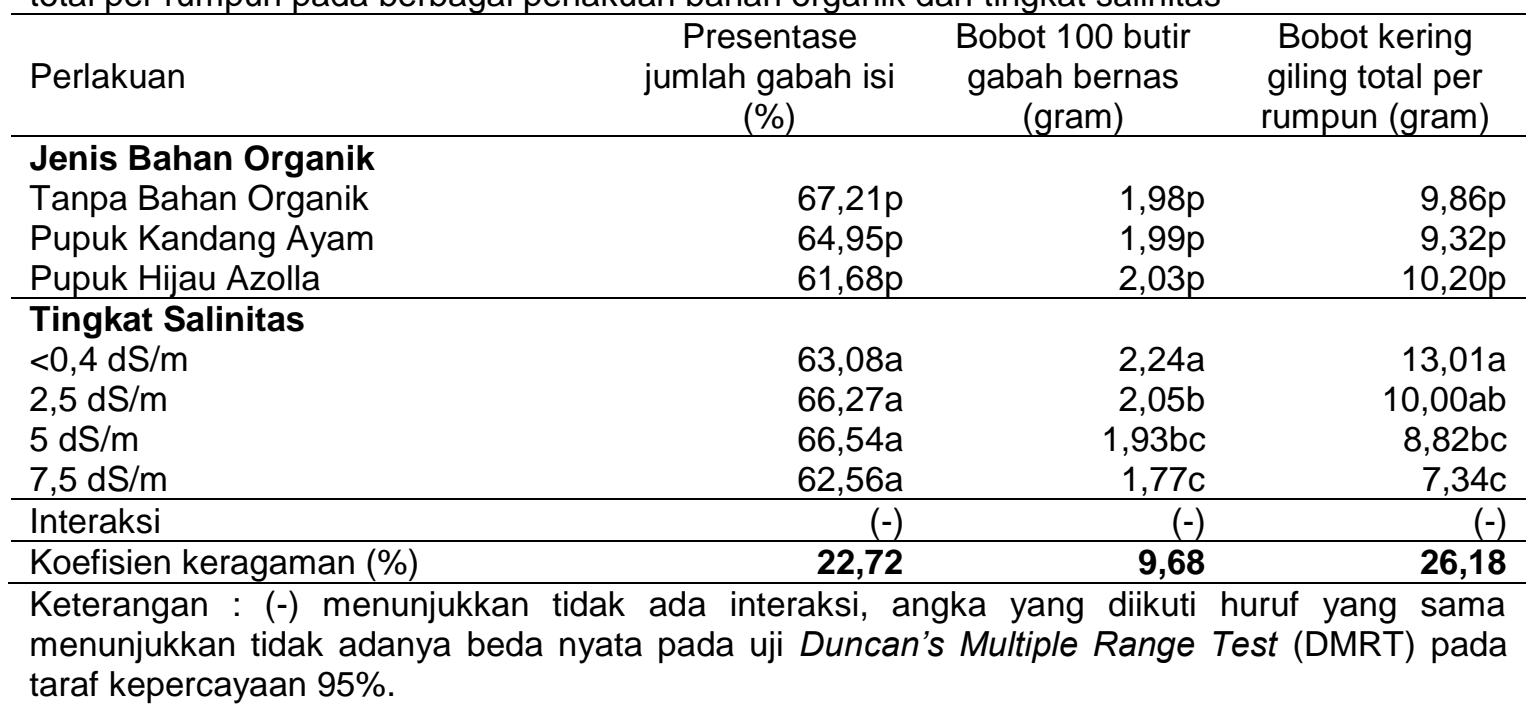

Bobot 100 gabah bernas (Tabel 7) menghasilkan beda nyata pada perlakuan tingkat salinitas. Perlakuan $2,5 \mathrm{dS} / \mathrm{m}, 5 \mathrm{dS} / \mathrm{m}$ dan $7,5 \mathrm{dS} / \mathrm{m}$ nyata lebih rendah dibandingkan perlakuan kontrol. Bobot 100 gabah bernas terendah pada perlakuan tingkat salinitas $7,5 \mathrm{dS} / \mathrm{m}$ menandakan pengisian bulir yang tidak sempurna. Hal tersebut disebabkan karena salinitas membuat ketidakseimbangan unsur hara pada tanaman karena adanya persaingan dengan unsur $\mathrm{Na}$ dan $\mathrm{Cl}$ dalam tanaman sehigga tanaman kekurangan unsur hara yang dibutuhkan, salah satunya unsur $P$. Unsur $P$ merupakan unsur yang berperan dalam pengisian bulir (Silva \& Uchida, 2000). Rendahnya unsur $\mathrm{P}$ yang dapat diserap tanaman diduga menyebabkan pengisian bulir yang tidak sempurna. Pengisian bulir yang tidak sempurna menyebabkan banyaknya gabah hampa yang dihasilkan sehingga bobot gabah kering giling total per rumpun yang dihasilkan juga rendah (Tabel 7).

\section{KESIMPULAN}

Terjadi penurunan pertumbuhan dan hasil secara nyata pada tanaman padi varietas IR-64 yang tercekam salinitas dimulai dari tingkat salinitas 2,5 dS/m pada parameter pertumbuhan luas daun, bobot segar tajuk, bobot kering tajuk, bobot kering akar, 
Fidian Nur Arifiani et al., / Vegetalika. 2018. 7(3): 30-40

panjang akar total, luas permukaan akar, bobot kering total tanaman, serta parameter hasil yaitu panjang malai, bobot malai, jumlah gabah per malai, bobot 100 butir gabah bernas dan bobot gabah kering giling total per rumpun yang menghasilkan nilai lebih rendah dibandingkan dengan perlakuan kontrol. Terdapat perbedaan pengaruh perlakuan jenis bahan organik pada berbagai tingkat salinitas. Pupuk kandang ayam mampu meningkatkan tinggi tanaman, sedangkan pupuk hijau azolla mampu meningkatkan bobot segar tajuk, bobot segar akar, bobot kering akar, jumlah anakan, bobot kering total tanaman dan komponen hasil yaitu jumlah malai yang lebih tinggi dibandingkan perlakuan kontrol, meskipun belum meningkatkan hasil. Namun, tidak terdapat interaksi antara perlakuan tingkat salinitas dan jenis bahan organik pada semua parameter.

\section{DAFTAR PUSTAKA}

Ahmed, B. A. O., M. Inoue, and S. Moritani. 2010. Effect of saline water irrigation and manure application on the available water content, soil salinity, and growth of wheat.

Arifin, Z. 2001. Pengaruh Macam dan Saat Pembenaman Produk Azolla terhadap Pertumbuhan dan Hasil Padi Sawah. Fakultas Pertanian. Universitas Gadjah Mada. Tesis.

Chaum, S., Y. Pokasombat, and C. Kirdmanee. 2011. Remediation of salt affected soil by gypsum and farmyard manure. AJCS 5(4): 458—465.

De Datta, S. K. 1981. Principles and Practices of Rice Production, John Wiley and Sons, New York.

Dikinya, O. and N. Mufwanzala. 2010. Chicken manure-enhanced soil fertility and productivity: Effects of application rate. Journal of Soil Science anf Environmental Management 1(3): 46-54.

Djukri. 2009. Cekaman salinitas terhadap pertumbuhan tanaman. Prosiding Seminar Nasional Penelitian, Pendidikan dan Penerapan MIPA. Fakultas MIPA, UNY.

Grubben, G. J. H. and S. Partohardjono. 1996. Plant Resources of South-East Asia No. 10 : Cereals. Prosea, Bogor.

Gupta, B. P., M. Muralidhar, K. O. Joseph, and K. K. Krishnani. 2001. Effect of salinity level and manure dose on the release of nutrients from brackishwater soil. Aquacult 2(2): 191-200.

Hoeft, B. 2001. Soil Fertility Management. Food and Agriculture Organization, Rome.

Islam, M. R., M. B. Hossain, A. B. Siddique, M.T. Rahman and M. Malika. 2014. Contribution of green manure incorporation in combination with nitrogen fertilizer in rice production. SAARC Journal Agriculture 12(2): 134-14 
Fidian Nur Arifiani et al., / Vegetalika. 2018. 7(3): 30-40

Levitt, J. 1980. Responses of Plants in Environtmental Stresses. Academic Press, London.

Maulida, E. I. 2011. Pengaruh Vermikompos, Pupuk Kandang, dan Pupuk Anorganik Terhadap Serapan Hara K dan Hasil Padi (Oryza sativa L.) Beras Merah di Lahan Sawah Kebak Kramat Karanganyar. Universitas Sebelas Maret. Skripsi.

Longstreth, D.J and P.S, Nobel. 1979. Salinity effects on leaf anatomy consequences for photosynthesis. Plant Physiol 63: 700-703.

Raja, W., P. Rathaur, S. S. John, and P. W. Ramteke. 2012. Azolla: an aquatic pteridophyte with great potential. International Journal of Research in Biological Sciences 2(2): 68-72.

Shaban, K. A., A. A. Mahmoud, A. Mansour, and M. G. A. El-Kader. 2009. Bio-fertilizer and organic manure affects rice productivity in newly reclaimed saline soil. Dynamic Soil, Dynamic Plant 3(1): 55-60.

Silva, J. A. and Uchida R. 2000. Essential Nutrients for Plant Growth: Nutrient Functions and Deficiency Symptoms. University of Hawaii.

Singh, S. S., A. K. Mishra, and R. S. Upadhyay. 2010. Potentially of Azolla as a suitable $\mathrm{P}$-biofertilizer under salinity through acid phosphatase activity. Ecological Engineering 36: 1076-1082. 